DigitALCOMMONS @WAYNESTATE -

\section{Michigan Journal of Counseling: Research, Theory and Practice}

Volume 38 | Issue 1

Article 3

3-1-2011

\title{
School Counselor Roles and Preparation
}

Barbara C. Trolley

St.Bonaventure University, btrolley@sbu.edu

Follow this and additional works at: https://digitalcommons.wayne.edu/mijoc

\section{Recommended Citation}

Trolley, B. C. (2011). School Counselor Roles and Preparation, Michigan Journal of Counseling, 38(1), 15-32. doi:10.22237/mijoc/ 1298937720 


\section{School Counselor Roles and Preparation}

\section{Barbara C. Trolley, PhD, CRC}

\section{St. Bonaventure University}

\section{Abstract}

Two fundamental questions are posed in this article, that of "What are the present day roles and tasks of school counselors?", and "What are academic preparation considerations with respect school counselor trainees?" A review of the literature pertaining to the role and preparation of school counselors is shared, as well as research pertaining to populations served by these professionals. The results of an exploratory study are shared. This study involved members of the New York State School Counselor Association who responded to a survey relating to on-site tasks, and academic preparation. Recommendations for future research that will continue to enhance clarity of school counselor roles, and training preparation are offered.

\section{School Counselor Roles and Preparation}

Counselor educators are frequently confronted with the daunting task of providing school counselor graduate students with a solid theoretical foundation, while at the same time, keeping abreast of practical skills essential to securing and maintaining such a position. Gone are the days when school counselor candidates are solely asked about their counseling theory. Interviews today are frequently packed with a multitude of practical applications of the job, such as responding to crisis oriented case scenarios and demonstration of psychoeducational lessons. These interviews are reflective of the actual expectations of school counselor roles and tasks within the educational system. Intimately tied to the discussions is the fundamental question of school counselor identity. With such a plethora of tasks assigned to school counselors, and the diversity in their roles across school districts and levels, counselor educators are left wondering how they may best communicate the professional identity of school counselors to their graduate students. This lack of uniformity is not only a concern in regard to the academic preparation of future school counselor professionals, but presents challenges in educating the community as to what they actually do, and defending their positions and the need for such professionals to school boards and legislators. Thus, the first question is posed: "What are the present day roles and tasks of school counselors?"

Once the roles and tasks of school counselors are further defined, the fundamental issue of how graduate trainees may receive adequate preparation

Barbara C. Trolley is a professor of counselor education and program director of the Counselor Education program at the Buffalo Center of St. Bonaventure University in St. Bonaventure, New York. She can be reached via email at: btrolley@sbu.edu. 
during their academic study is raised. It is still as an essential element of graduate study to incorporate classic counseling theories and techniques. However, educators must take a step further and examine what are the essential practical skills with which trainees need to be equipped. In line with this area of exploration is the consideration of how such academic preparation may be best presented to trainees, e.g.,

- should classes involve guest speaker and/or adjunct professors who are practicing counselors;

- what kinds of assignments might best provide trainees with such skills; and

- $\quad$ are these concerns primarily left to the site supervisor to address? While the format of academic classes and assignments is beyond the scope of this article, it is worthwhile to pause and give some reflective thought to this area, which is the second focus of the current discussion: "What are academic preparation considerations with respect school counselor trainees?"

Therefore, the purpose of this article is twofold: to review the plethora of school counselor roles and tasks; and to examine the academic preparation of such graduates with respect to the job demands they face; all with an overarching goal of looking at the professional identity of school counselors. These goals will be accomplished through a review of the literature and provision of results from an initial exploratory study.

\section{School Counselor Roles \& Tasks}

The American School Counselor Association (ASCA) has set forth a well-defined description of the primary role of school counselors: "Professional school counselors are certified/licensed educators with the minimum of a master's degree in school counseling and are uniquely qualified to address the developmental needs of all students through a comprehensive school counseling program addressing the academic, career and personal/social development of all students" (ASCA, 2011). Despite the specifications shared above, school counselor graduates often encounter widely diversified job expectations. While there may be clarity in the general role of school counselors, there remains much discrepancy in their tasks. For example, some graduates are assigned administrative tasks such as scheduling and disciplinary functions, while other are involved in direct counseling. This task inconsistency confounds practicing counselors' ability to delineate appropriate and inappropriate assignments, challenges educators as to how to sufficiently prepare graduate students, and makes it difficult to educate other professionals and lay persons as to the school counselor role. A first step in providing clarity to the school counselor role is the development by school districts of job descriptions and evaluations specific to school counselors. The reality is that many school counselors are working in settings which do not a have a school counselor job description and are continuing to have performance evaluations similar to those conducted for teachers. In addition, even when such documentation exists, the outdated notions that school counselors are 'guidance counselors' persist. Guidance, while an essential task performed by these professionals, is not the limit of their role.

An additional glimpse into the overall role and tasks of school counse- 
lors may be directly and indirectly ascertained from existing research. The University of Massachusetts' Center for School Counseling Outcome Research and Evaluation has conducted extensive empirical studies which highlight the effectiveness of school counselors in the area of career knowledge, academic achievement, and improved social skills (http://www.umass.edu/

schoolcounseling/). Similarly, ASCA presents diverse empirical evidence that school counselors have a positive impact on children (http:// www.schoolcounselor.org/content.asp?contentid=241).

Clearly, school counselors are to assist ALL students in their academic, career, and personal-social development; these focus domains are tied to the educational goals of students. While these professionals definitely assist students with academic and career decisions, they are also addressing many mental health issues of students that negatively impact on students' educational success. Thus, one of the first more specific delineation of the school counselor role is found in the description of school counselors as educators and mental health counselors (Anderson, Perryman \& Tejada, 2006; Paisley, ZiomekDaigle, Getch \& Bailey, 2007; Perkins, Oescher \& Ballard, 2010), and is further evident in the next section in which the presenting problems of today's students are discussed. School counselors frequently find much job satisfaction in providing such therapeutic services to students (Harris, 2009), and their educator role is inherent in the ASCA statement positioning these professionals as key players in school improvement and as supporters of No Child Left Behind (Dahir, 2004). A fundamental underlying issue in this role is that of whether or not school counselors are qualified and adequately prepared to provide mental health interventions. This issue has been highly discussed in New York State, with the passage of the Mental Health Counselor License. Proponents suggest it is essential that school counselors become Licensed Mental Health Counselors in order to adequately provide services and compete with other disciplines for reimbursement and jobs. Opponents suggest the license is not necessary, requirements to obtain both credentials are extensive, and to do so is watering down the identity of both areas of counselor specialization.

A second important specific role of school counselors is that of leadership (Janson, Stone \& Clark, 2009; McMahon \& Akos, 2007; McMahon, Mason \& Paisley, 2009). School counselors are frequently the ideal candidates to lead the educational team in terms of systemic changes and evidenced-based practices and it has been found that this leadership role has a significant relationship to the service delivery of these professionals (Shillingford \& Lambie, 2010). This role is most evident when a crisis within a school occurs. Typically, it is the school counselor who is approached to assist students, staff and families in the early crisis management, as well as the longer term follow up.

From this leadership role is the closely aligned function of advocacy. House and Sears (2002) stated that school counselors need to move beyond their roles as helper-responders assume advocacy and leadership roles for the success of all students. This role of school counselors, as well as the need for pre-service training as advocates and academic advisors was supported by Martin (2002) in referencing the Transforming School Counseling Initiative. School counselors frequently know the students' needs and abilities the best 
and can advocate on their behalf, that of their family, and even the school. For example, while school counselors are not always required members of committees on special education, they frequently can provide vital information in the goal planning process, advocating for the needs of the students. Considering that school counselors are seeing more and more students with Individualized Education Plans (IEP), it is crucial that their leadership in this domain be recognized. Singh, Urbano, Hatson and McMahon (2010) further suggested that school counselors need to be agents of change within their school systems. A simplistic example of this function is working with school staff and administrators to develop district-wide policies related to cyberbullying, not just bullying.

An additional, equally important advocacy role is that of school counselors' efforts to support and educate others to their profession. In these national economic times it is even more imperative to develop a unified definition of their profession and for school counselors to self-advocate for their value to the school systems. One of the best ways to establish this worth is through data driven outcome studies of a comprehensive school counseling programs developed according to the ASCA model (Beale, 2004; Carey \& Dimmit, 2008; Dahir \& Stone, 2009; Luke \& Scarborough, 2008; Ullendahl, Stephens, Buono \& Lewis, 2009; Walsh, Barrett \& DePaul, 2007). Simply conducting a task analysis of daily activities and conversion of this summary into a pie chart can be beneficial data to present to a school board in defense of the school counselor role. Likewise, offering to do presentations to parents and school staff on a gamut of topics and/or on their role, or getting involved in focus groups may be of assistance in clarifying the school counselor profession.

While school counselors are an important position to be leaders within their community, they are similarly able to take on roles as team players, collaborators. From the start, it is essential that school counselors and teachers identify effective partnerships in order to enhance student learning and achievement (Sink, 2008). An example of such collaboration between these two groups is in terms of guidance curriculum lessons (Dodson, 2009). Teachers are present with the student population throughout the day and may have the best handle on what are their needs. By communicating these needs to the school counselors these professionals may cooperatively work together to develop psychoeducational lessons pertinent to these concerns such as anger management and social skills. Ward, Evans and Couts (2010) further addressed the next level of collaboration, that of working with administrators. The former group can assist in establishing a positive classroom environment while principals can address an overall safe and orderly learning environment. School counselors also work closely with school psychologists in regard to further assessment of student issues (Romano \& Kachgalm, 2004). In addition, collaboration between school counselors and school social workers may be essential in obtaining needed services for students and their families in the community, such as housing, food, and medical care. Wrap around services are a fertile area for such collaboration. Whether it is in terms of educational attainment, mental health enhancement, or basic issues of safety, it behooves all members of the educational setting to work together as a team, delineating tasks and responsibilities, as well as establishing effective communication networks. School counselors are also key players in the development of partnerships with families and the 
community (Epstein \& Van Voorhis, 2010). Teamwork is vital for the opportunity for diverse perspectives and abilities to intervene, everyone being on 'the same page', and shared workload.

\section{School Counselor Preparation}

As can be seen from the prior discussion, school counselors' roles vary, and the tasks they are assigned are vast. In review of these issues the academic preparation of these professionals should be examined. A plethora of counselor education programs exist nationally. Certainly, the Council for Accreditation of Counseling and Related Education Programs (CACREP) set forth standards in regard to the preparation of school counselors (Branthoover, Desmond \& Bruno, 2010; Milsom \& Akos, 2007). Proficiency in numerous core areas is required such as group work, multicultural competencies, helping relationships, assessment, research and program evaluation, career counseling, human growth and development, and professional identity and there are state educational requirements that must be followed.

In addition, stated educational departments set forth criteria in the preparation of professional counselors. However, not all programs are CACREP accredited and guidelines are not always adhered to resulting in programs with varying credit hours, plans of study, and specifications for the advanced certificate of specialization, (the advanced certificate of specialization refers to required coursework and field experiences to achieve permanent certification in school counseling). To add to the diversity in preparation of school counselor candidates, graduates in training in some states may independently contact, e.g., the Board of Cooperative Educational Services (BOCES) to have their credentials reviewed, thus involving an additional body of credentialing and coursework specification.

In light of the inconsistency and variations in Counselor Education programs, academicians are left with trying to establish effective pedagogical practices in training school counselor graduate students. Most educators would agree that they provide school counselors in training with excellent fundamental coursework in the theoretical aspects of these domains. Alumni frequently return and affirm their counseling theory and skill strength. What may fall short is the practical aspects of the role of the school counselor. Questions frequently raised by graduate students in training include:

- How do I do scheduling?

- What are IEP? 504 Plans?

- What are college applications like and how do I find scholarship information?

- What is my role in the crisis response team? How do I provide postvention?

- How do I develop relationships/partnerships with teachers, administrators, families?

- How do I address 'cutting', and gang behavior?

- What are the rules and policies in regard to cyberbullying?

- How do I deal with Internet addictions? Gambling?

First and foremost, school counselor preparation programs must abide by 
standards set forth by their accrediting bodies and professional organizations. State requirements for permanent school counselor certification also impact on such areas as specific number of credit hours that are required. However, in this day and age, counseling theory and practice are necessary but not sufficient aspects of training. CACREP in 2009 added areas related to addictions and trauma response to their standards. It is true that many aspects of one's role are learned on the job and that there are limits within one's role and competencies. However, with the increasing aspect of mental health and diversity issues in schools, the competitive job market, and litigation, it is crucial that graduate students are given some exposure to the more practical aspects of the job. Such blend of theoretical based training, embedded in evidenced-based practices and practical skills, will serve to produce more competent professionals.

Attention must also be paid to post-graduate education, not only in terms of certificates of advanced study and various professional development units required by school districts, but also in terms of usefulness. Workshops, conferences, and audited courses are excellent ways to supplement graduate coursework and updated on current practices. In addition, there is a need for supervision and consultation opportunities (Devlin, Smith, \& Ward, 2009; Dollarhide \& Miller, 2006; Rutter, 2007; Somody, Henderson, Cook \& Zambrano, 2008) beyond graduate school. The barriers to supervision include: few school counselors at times in one setting; absence of senior counselors; lack of time; and absence of supervision courses in masters level courses. In New York State, an additional obstacle is the focus of supervision on mental health issues rather than educational concerns for those school counselors seeking the license. Supervision, however, is the basic building block for quality of care considerations and professional development, and cannot be overlooked. The ability of school counselors to develop a professional identity, moving from dependence on experts to self-validation, as indicated by Gibson, Dollarhide \& Moss (2010), cannot occur in a vacuum. Novice school counselors need sounding boards, constructive feedback, and support, all of which can be found in supervision. Intimately tied into this need for supervision is the necessity for states to lay down specific requirements of school counselors to further enhance continuity in training, fairness in evaluation, and expertise in delivering quality services.

Beyond these issues, it has been found that values of graduate students and practicing school counselors vary (Busacca, Beebe\& Tornan, 2010). This is a fertile area of supervision discussion. In light of high caseloads, difficult cases, and lack of clarity in the school counselor role, these professionals are susceptible to burnout. Supervision may be a desperately needed avenue of support to maintain the mental health, and job satisfaction of these professionals. Brott (2006) found an inverse effect between collective self-esteem and burnout. Those school counselors who had higher collective positive perceptions of the field were less likely to experience burnout. Even if formalized supervision is not available, networking with peers to address concerns, learn new skills and gain support may help to strengthen school counselors' perceptions of their roles and longevity in them. Membership in honor societies such as Chi Sigma lota can also assist with these goals (Luke \& Goodrich, 2010).

A final consideration in the academic preparation of school counselors beyond those areas previously discussed is that of the development of strength- 
based identities of these professionals (Lewis \& Hatch, 2008). These authors suggested that school counselors be trained in culturally relevant and evidenced based practices, in order to support the learning development of all youth. A core aspect of this strength-based paradigm is the ability to develop strong, comprehensive, data driven programs (Wilkerson \& Eschbach, 2009). This data is essential to solidify the core work done by these professionals, for continuity in programming, and in an effort facilitate communication as to the role of school counselors.

\section{Summary}

It is evident from the literature review that while guidelines as to the role and preparation of school counselors exist, there are many variations and ambiguities as well. There is also very little research which exists that pertains to the adequacy of school counselor preparation, given the current demands of the job. I, in collaboration with a colleague from another university, initially informally asked practicing school counselors in regard to their role, tasks and academic preparation. Based on this feedback, I then developed three surveys based on the ASCA standards. It is important to note that the generalizations from this study are limited, due to the very small sample size, and the data being received from school counselors only from New York. The results are presented simply as a means of stimulating thoughts and ideas about the profession, and suggested areas for future empirical focus.

\section{Purpose of the Study}

The purpose of this study was to explore the adequacy of the preparation of school counselors for their job functions, specifically, in answering the following two questions:

"What are the present day roles and tasks of school counselors?"

"What are academic preparation considerations with respect school counselor trainees?"

\section{Method}

\section{Subjects}

Participants were randomly sampled within members of the New York State School Counselor Association (NYSSCA). All participants were practicing school counselors at either the elementary, middle, or high school level. A total of 26 school counselors across New York State responded to the survey. Specifically, 6 elementary school counselors, 7 middle school counselors, and 13 high school counselors participated in this study. The participants represented primarily were from the Buffalo and New York City area, with isolated surveys coming from the Albany, Medina and Rochester areas. The American School Counselor Association (ASCA) and the University of Massachusetts Center for School Counseling Outcome Research and Evaluation were also contacted. However, the survey is still in the editorial review stage of their research committees. 


\section{Procedure}

The President of NYSSCA and administrative board members were contacted for permission to send the survey via an email to the members' listserv. A brief description of the study was given in the email that was consistent with the description at the top of each survey. Specifically, the purpose of the study was addressed as trying to gain an understanding of what were their roles in the schools, and how well did they feel academically prepared to perform them. Names were not required on the survey to insure confidentiality and comfort in responding. Participants were given the option of either emailing the completed surveys or returning a hard copy to my university address if they desired to keep all identifying information confidential. Once the surveys were returned, they were kept in a locked file on campus to preserve safety and confidentiality of the material. The only additional person that had access to the completed surveys was a graduate assistant.

\section{Instrument}

I developed a survey specific to the elementary, middle and high school level, based on the ASCA standards. Specifically, participants, using a 3 point likert scale, were asked to rate their job functions and their academic preparation in two areas:

- Delivery System [Classroom Guidance, Individual Student Planning, Responsive Services, System Support]

- Collaboration [Parents, Students, Teachers, Administrators, Community]

Their job functions were broken down into both their actual duties and ones they preferred and they were further asked to estimate the percentage of time spent on these tasks. In addition, there was a space at the bottom of each survey to add any additional activities or comments.

The Likert scale was quantified in the following manner:

\begin{tabular}{c|c}
\hline$\#$ & Definition \\
\hline $\mathbf{1}$ & $\begin{array}{c}\text { Excellent preparation/High degree of actual activities assigned/High } \\
\text { preference for the activity }\end{array}$ \\
\hline $\mathbf{2}$ & $\begin{array}{c}\text { Adequate academic preparation/Moderate degree of actual activities } \\
\text { assigned/Moderate preference for the activity }\end{array}$ \\
\hline $\mathbf{3}$ & $\begin{array}{c}\text { Inadequate preparation/Low degree of actual activities assigned/ low } \\
\text { preference for the activity }\end{array}$ \\
\hline Time of & Using the following categories, (the averages do not have total \\
& $100 \%):$ \\
& $\begin{array}{c}\text { Majority of Time }(\mathrm{M})=75 \%-100 \% \\
\text { Reasonable Amount of Time }(\mathrm{R})=50 \%-74 \% \\
\text { Some Amount of Time }(\mathrm{S})=25 \%-49 \% \\
\text { Little Amount of Time }(\mathrm{L})=<25 \%\end{array}$ \\
\hline
\end{tabular}




\section{Analyses}

Means and percentages were calculated for each of the response area. The open-ended questions were summarized by the graduate assistant, to reduce bias.

\section{Results}

\section{Duties.}

Elementary school counselors reported most of their time was spent in Responsive Services, middle school counselors in Responsive and Individual Planning Services, and at the high school level, school counselors' time was devoted to Guidance and Individual Student Planning activities. The results of the study for "Delivery" duties are presented in Table 1.

Table 1

Delivery Duties

\begin{tabular}{lllll}
\hline & Guidance & $\begin{array}{l}\text { Individual } \\
\text { Student } \\
\text { Planning }\end{array}$ & $\begin{array}{l}\text { Responsive } \\
\text { Services }\end{array}$ & $\begin{array}{l}\text { Systems } \\
\text { Support }\end{array}$ \\
\hline Elementary & Little & Some & Reasonable & Some \\
\hline Middle & Little & Reasonable & Reasonable & Some \\
\hline High & Reasonable & Reasonable & Some & Some \\
\hline
\end{tabular}

The respective primary targets of collaboration at each level were teachers, administrators, and parents. The results for the participants' responses to "Collaboration" duties are presented in Table 2.

Table 2

Collaboration Duties

\begin{tabular}{llllll}
\hline & Parents & Students & Teachers & $\begin{array}{l}\text { Admin- } \\
\text { istrators }\end{array}$ & $\begin{array}{l}\text { Communi- } \\
\text { ty }\end{array}$ \\
\hline Elementary & Little & Some & $\begin{array}{l}\text { Reasona- } \\
\text { ble }\end{array}$ & Some & \\
\hline Middle & Little & Little & Little & Some & Little \\
\hline High & Reasonable & Some & Some & Some & Some \\
\hline
\end{tabular}


The qualitative responses for "Additional Duties" are listed in Table 3

Table 3

Additional Duties

\begin{tabular}{|c|c|c|}
\hline Elementary & Middle & High \\
\hline $\begin{array}{l}\text { NYS (New York State) } \\
\text { assessments Paperwork } \\
\text { Coordinate with DSS } \\
\text { (Department of Social } \\
\text { Services) } \\
\text { Intervention } \\
\text { Bus duty } \\
\text { Family counseling } \\
\text { Peer Helpers } \\
\text { Professional development } \\
\text { Union } \\
\text { Committees } \\
\text { IEPs (Individualized Edu- } \\
\text { cation Plans) } \\
\text { CSE (Committee on Spe- } \\
\text { cial education) participant, } \\
\text { referral team } \\
\text { Hall duty } \\
\text { State testing } \\
\text { Student intervention team, } \\
\text { chair person }\end{array}$ & $\begin{array}{l}\text { Master schedules } \\
\text { Student schedule changes } \\
\text { Evening out classroom } \\
\text { sizes } \\
\text { Politics of education sys- } \\
\text { tem } \\
\text { Special education all as- } \\
\text { pects } \\
\text { IEP counseling } \\
\text { CSE } \\
\text { IEP related work } \\
\text { Classroom coverage } \\
\text { Proctoring }\end{array}$ & $\begin{array}{l}\text { Master schedule } \\
\text { IEP related work/ } \\
\text { Documents } \\
\text { Class coverage } \\
\text { Proctoring } \\
\text { Program changes } \\
\text { Field trips } \\
\text { Testing } \\
\text { Parent programs } \\
\text { Bus duty } \\
\text { Crisis support } \\
\text { Transcript review }\end{array}$ \\
\hline
\end{tabular}

Preparation, actual and preferred tasks.

Delivery Domain: In terms of the Delivery domain, elementary participants reported being highly prepared in the Guidance, Responsive Services and Systems Support areas; felt that their actual duties were concentrated in Individual Student Planning, Responsive Services and Systems Support parts of the job; and preferred the Guidance section of service. Middle School respondents felt most prepared in the areas of Individual Student Planning and Systems Support; indicated all four areas of this domain were actual tasks; and rated Systems Support followed by Guidance activities as their preferred tasks. The result of the high school participants indicated they felt highly prepared in all areas except Responsive Services; their actual duties fell primarily into all parts of this domain; and their preferred duties being that of Responsive Services and Systems Support.

Collaboration: Elementary school counselors indicated they felt moderately prepared for collaboration with parents, students, teachers and administrators; their actual tasks involved collaboration with all parties; and their preferred collaboration to be with students and parents. Middle school participants felt most prepared for collaboration with students, teachers and administrators; actually worked most with all groups except administrators; and preferred to col- 
laborate with parents and the community. High school respondents reported being prepared in all areas except collaboration with the community; worked most with the students and community; and preferred community collaboration.

\section{Discussion}

As stated earlier, generalizations from the results of this study are limited to the nature of the small sample size and source of the respondents. However, some of the 'trends' of the results are consistent with the literature that has been reviewed.

\section{Duties}

Whiston and Quinby (2009) found that elementary school counselors tend to spend most of their time in terms of Guidance Curriculum and Responsive Delivery services. So too, participants at this level in this study indicated similar duties. This finding makes sense in terms of the primary grade levels being the exposed to a plethora of psycho-educational lessons on topics such as character education and bullying, as well as issues of transition to school, and those related to peers and family, being discussed at this age level. At the middle school level, Whiston and Quinby noted that Responsive Delivery and Guidance Curriculum as the primary tasks, while respondents in this study indicated Guidance and Individual Student Planning as primary activities. It would seem reasonable, in light of the social and educational transitions, and the 'drama' that occur at this level, that Responsive Services would surpass those of Individual Student Planning. It is not known how many of this study's participants were working with students with IEP's, which may have had an impact on their focus. It would be reasonable to consider that if school counselors are assisting students with special needs, that more individual planning may be involved. Lastly, at the high school level, Whiston and Quinby noted an equal focus on Individual Student Planning, and Responsive Services, while respondents in this study mentioned Guidance and Individual Student Panning as their focus. With long term vocational plans being an emerging issue at this level, it would make sense that more time was spent on Individual Student Planning. The Responsive Services appears to be a consistent theme, and one in line with mental health issues increasing within the student body, as discussed in the literature review. Students with mental health issues, and those in crisis would warrant more individual time to stabilize situations, develop plans, and make referrals. As students transition from middle to high school, themes at the basis of these services may change from those of social adjustment and transition to numerous teachers, to issues of substance abuse, dating conflicts, vocational fears, and mental health classifications.

\section{Preparation, actual and preferred tasks.}

It is difficult to make any specific generalizations with the findings in this area of the study based on the small sample size and the fact that these results are based solely on New York State participants. The findings are also limited due to the fact that some initial contradictions exist between stated duties and 
the discussion of actual tasks. One explanation for this may be the differential reading/perception of the questions by respondents in these two main areas of inquiry. Another reason for this inconsistency may be that very specific questions were posed for the preparation and task sections, thus triggering more concrete examples of their job function. What are perhaps the most important pieces of information to gleam from this area is that school counselor preparation does not completely match the requirements of the job, and that actual and preferred tasks do not always coincide.

It is essential that academic programs pay attention to the skill aspects of a school counselor position, in addition to the knowledge components. Specifically, a 'scientist-practitioner' model is essential. One means of ascertaining key roles of school counselors is to follow up with alumni as to the tasks they are performing, and how they feel about such duties. In line with is option would be to bring in alumni who are practicing school counselors at the elementary, middle and high school levels to discuss with current graduates what tasks they perform and how to develop the related skills. This could also be accomplished through the hiring of these guest speakers as adjunct professors. Certainly keeping abreast of changes as addressed by ASCA and CACREP are additional areas of knowledge of current skills needed to teach. Finally, as more research is done in terms of the school counselor role and effectiveness, more continuity in job descriptions and assigned duties will hopefully emerge.

\section{Recommendations}

\section{Future Research}

Further empirical research into the preparation and roles of school counselors is warranted. While requirements of academic programs are regulated by state education mandates, professional organizations and accreditation regulations, additional insight into the training needs of graduate students through empirical study is essential. The question of whether school counselors are ready and able to effectively execute their duties post-graduation must be raised. This evaluation is dependent on the validity and reliability of the tools to complete these assessments. Such analysis is relevant to the quality of care provided, and graduates' marketability, i.e. ability to secure and maintain jobs.

In addition, research studies in which current school counselor job descriptions are analyzed and a summary of job credentials and duties is compiled would be helpful in ascertaining common areas of agreement and those of disagreement as well as domains which need to be strengthened. Results from such a study may be one step closer to delineating a more consistent profile of the profession.

Beyond the continuity in credentials and hierarchy of communication, much diversity exists as to how duties are defined. While it is beyond the scope of this article to summarize all aspects of delineated tasks across these descriptions, a brief sample of a few of the job descriptions will be shared:

- Curriculum implementation

- Counseling, consultation, referral and advocacy 
- Planning, implementation and evaluation of school counseling programs

- Involvement in: program management, school climate, school improvement, student management, professional growth and development, and school/community relations

- Assistance with transition to high school; Positive Behavior Intervention System (PBIS); Academic Intervention Services

Closely tied to this area of research is that of examining idiographic duties of school counselors based on the population served and region in which they work. For example, Dellana and Snyder (2004) examined the quality of counseling services offered in a rural minority high school. Henderson, Cook, Libby and Zambrano (2007) also conducted a study in which dimensions affecting school counselor identity development were examined. These dimensions included: fulfilling appropriate roles, increasing competence, committing to working with students, and increasing competence. While the majority of roles and tasks will be unified across school counselors, there may be 'nuances' which exist depending on confounding variables such as those mentioned. As Gale and Austin (2003) indicated, there may still be 'unity in diversity'; a 'collective identity'. The question of appropriate roles and increased continuity in services provided might be better buffeted by the development clear job descriptions and course evaluations designed specifically for school counselors.

To aid in this effort, ASCA has posted several helpful guidelines for these items:

- School Counselor Performance Standards

http://ascanationalmodel.org/content.asp?pl=33\&sl=35\&contentid=35

- School Counselor Competencies

http://ascamodel.timberlakepublishing.com/files/SCCompetencies.pdf

- School Counselor Performance Evaluation Tool

http://ascanationalmodel.org/content.asp?pl=33\&sl=35\&contentid=35

\section{Professional and Accrediting Organizations' Guidelines}

Another necessary but not sufficient condition in terms of review is that of the examination of the "do's" and "don'ts" for school counselor duties set forth by ASCA in The ASCA National Model: A Framework for School Counseling Programs (2005). Likewise, CACREP has very specific criteria in regard to programs preparing school counselors, specific to the domains of Foundations; Counseling, Prevention, and Intervention; Diversity and Advocacy; Assessment; Research and Evaluation; Academic Development; Collaboration and Consultation; and Leadership. Oftentimes, it is not the knowledge of what is appropriate or inappropriate on the job, but rather the difficulty in saying no to these tasks. This is especially true for the novice counselor awaiting tenure and is probably accurate for the majority of school counselors in light of all the ongoing budget cuts who are fearful of losing their jobs. School counselors must utilize all of their communication and advocacy skills to effectively share their abilities and limits with the 'powers that be' on site. Professional organizations such as ASCA and CACREP are there to be of great assistance to their members on many levels, not the least of which is identity clarification and unity efforts (Schneider, 2009). 


\section{Other}

As previously mentioned, it may be helpful to invite practicing school counselors come to be guest speakers, adjuncts professors, or even workshop leaders. Another option is to develop partnership rotations, whereby students, in addition to their field site requirements, have an opportunity to voluntarily visit a variety of schools to shadow school counselors for a day. This would offer diverse counseling styles, tasks and issues at different levels of school and would help to build a gamut of practical skills and perhaps further define student interests.

It may also be helpful to review standardized instruments such as the School Counseling Program Component Scale (Hatch \& Chen-Hayes, 2008). Looking at such tools may assist in giving practicing counselors a better idea of what they need to be doing, administrators a better sense of pertinent evaluation areas, counselor educators and understanding of areas of training for their graduate students, and the community at large increased comprehension of school counselor roles.

In summary, school counselors and educators must collaborate to further define the role, appropriate tasks, and necessary preparation of these professionals. Similar to the empowerment of counselors in working with clients who are oppressed (Hipilito-Delg \& Lee, 2007), the school counseling profession must become empowered to fight for its recognition and survival. Equally important is an open, collaborative dialogue among professionals within school, the community and counselor education preparation programs so that roles are understood and respected.

Research into this area is beginning, as evaluations of pre-counselors' and administrators' perceptions of the role of the school counselor have been explored (Ross \& Herrington, 2006), and support from administration in clarifying the school counselor role is emphasized (Lieberman, 2004). Finally, philosophically, narrow views of any profession must be reconsidered in light of the complex issues confronting youth today. Toporek, Blando, Chronister, KwongLiem, Hsin-Ya and VanVelsor (2009) have addressed this issue in their discussion of serving the whole client through the creative blending of roles of counselors. This does not mean that school counselor roles are free-floating and unclear, but rather an integrated, unified sense of self and direction is important. It is often said that a job is what we do and not who we are. However, the reverse may be true in the case of school counselors in that it is imperative to know who we are in order that we know what to do.

\section{References}

American School Counselor Association (2005). The ASCA national model: A framework for school counseling programs $\left(2^{\text {nd }} E d\right)$. Alexandria, VA: Author.

American School Counselor Association (2011). The role of the school counselor. Retrieved 1/15/11 from: http://www.schoolcounselor.org/ content. asp? $\mathrm{pl}=325 \& \mathrm{~s}=133 \&$ contentid=240. 
Anderson, A., Perryman, K. \& Tejada, L.(2006). At issue: School counselors' professional identity. Counseling Today, 48(8), 14-15.

Bauman, S. (2008). The role of elementary school counselors in reducing school bullying. The Elementary School Journal. 108(5)., 362-375.

Beale, A.V. (2004). Questioning whether you have a contemporary school counseling program. The Clearing House. 78(2), 73-76.

Branthoover, H., Desmond, K.J. \& Bruno, M. (2010). Strategies to operationalize CACREP standards in school counselor education. Journal of Counselor Preparation \& Supervision, 2(1), 37-47.

Brott, P. E.(2006). Collective self-esteem and burnout in professional school counselors Professional School Counseling, 10(2), 179-188.

Busacca, L.A., Beebe, R.S. \& Tornan, S.M..(2010). Life and work values of counselor trainees: A national survey. Career Development Quarterly, 59(1), 2-18.

Carey, J. \& Dimmitt, C. (2008). A model for evidence-based elementary school counseling: Using school data, research, and evaluation to enhance practice. The Elementary School Journal, 108(5), 422-430.

Dahir, C. (2004). Supporting a nation of learners: The role of school counseling in educational reform. Journal of Counseling \& Development, 82, 344353.

Dahir, C.A. \& Stone, C.B. (2009). School counselor accountability: The path to social justice and systemic change. Journal of Counseling \& Development, 87, 12-20.

Dellana, S. A. \& Snyder, D. (2004). Student future outlook and counseling quality in a rural minority high school. The High School Journal. 88(1), 27-41.

Devlin, J., M.; Smith, R. L. \& Ward, C. A(2009). An Adlerian alliance supervisory model for school counseling. Journal of School Counseling, 7, 1-23.

Dodson, T. (2009). Advocacy and impact: A comparison of administrators' perceptions of the high school counselor role. The Free Library. Retrieved October 07, 2010 from http://www.thefreelibrary.com/Advocacy and impact: a comparison of administrators' perceptions of...-a0206850828.

Dollarhide, C.T.\& Miller, G. M.(2006). Supervision for preparation and practice of school counselors: Pathways to excellence. Counselor Education \& Supervision, 45(4), 242-252. 
Epstein, J.L. \& Van Voorhis, F.L. (2010). School counselors' roles in developing partnerships with families and communities for student success. Professional School Counseling, 14(1), 1-14.

Gale, A. U. \& Austin, B. D. (2003). Professionalism's challenges to professional counselors' collective identity. Journal of Counseling \& Development, 81, 3-10.

Gibson, D. M., Dollarhide, C. T. \& Moss, J. M. (2010). Professional identity development: A grounded theory of transformational tasks of new counselors. Counselor Education and Supervision, 50(1), 21-38.

Harris, B.(2009). Extra appendage' or integrated service? School counselors' reflections on their professional identity in an era of education reform. Counseling \& Psychotherapy Research 9(3), 174-181.

Hatch, T.; Chen-Hayes, S. F. (2008). School counselor beliefs about ASCA national model school counseling program components using the SCPCS. Professional School Counseling, 12(1), 34-42.

Henderson, P., Cook, K., Libby, M. \& Zambrano, Elias (2007). Today I feel like a professional school counselor. Guidance \& Counseling, 21(3), 128142.

Hipilito-Delg, C. \&.Lee, C.. (2007). Empowerment theory for the professional school counselor: A manifesto for what really matters. Professional School Counseling, 10(4), 327-332.

House, R. \& Sears, S. (2002). Preparing school counselors to be leaders and advocates: A critical need in the new millennium. Theory Into Practice, 41(3), 154-162.

Janson, C., Stone, C, \& Clark, M A.(2009). Stretching leadership: A distributed Perspective for school counselor leaders. Professional School Counseling, 13(2), 98-106.

Lambie, G. \& Williamson, L. (2004). The challenge to change from guidance counseling to professional school counseling: A historical proposition. Professional School Counseling, 8(2), 124-131.

Lewis, R. E. \& Hatch, T. (2008). Cultivating strengths-based professional identities. Professional School Counseling, 12(2), 115-118.

Lieberman, A. (2004). Confusion regarding school counselor functions: School leadership impacts role clarity. Education, 124(3), 552-558. 
Luke, M. \& Goodrich, K. (2010). Chi Sigma lota chapter leadership and professional identity development in early career counselors. Counselor Education \& Supervision, 50(1), 56-78.

Luke, M. \& Scarborough, J.L. (2008). School counselors walking the walk and talking the talk: A grounded theory of effective program implementation. Professional School Counseling. 11(6), 404-416.

Mason, E. C. M.; McMahon, H.G. (2009). Leadership practices of school counselors. Professional School Counseling, 13(2), 107-115.

Martin, P. (2002). Transforming school counseling: A national perspective. Theory into Practice, 41(3), 148-153.

McMahon, H. G., Mason, E. C. M.\& Paisley, P.O. (2009). School counselor educators as educational leaders promoting systemic change. Professional School Counseling, 13(2), 116-124.

Milsom, A. \& Akos, P. (2007). National certification: Evidence of a professional school counselor? Professional School Counseling, 10(4), 346-351.

Ott, C.H. \& Doyle, L.H. (2005). An evaluation of the small group norms challenging model: Changing substance use misperceptions in five urban high schools. The High School Journal, 88(3), 45-55.

Paisley, P., Ziomek-Daigle, J. Q., Getch, Y. F. \& Bailey, D. (2007). Using state standards to develop professional school counselor identity as both counselors and educators. Guidance \& Counseling, 21(3),143-151.

Perkins, G., Oescher, J. \& Ballard, M.(2010). The evolving identity of school counselors as defined by the stakeholders. Journal of School Counseling, 8(31).

Romano, J. L.\& Kachgalm, M. M. (2004). Counseling psychology and school counseling: An underutilized partnership. The Counseling Psychologist, 32, 263-269.

Ross, W. \& Herrington, D. (2006). A comparative study of pre-professional counselor/principal perceptions of the role of the counselor in public schools. National Forum of Educational Administration and Supervision Journal, 23(4E), 1-18.

Rutter, M. E. (2007). Group supervision with practicing school counselors. Guidance \& Counseling, 21(3), 160-167. 
Schneider, S. (2009). Learning about strength, identity, unity from ASCA. Counseling Today, 52(6), 56-57.

Singh, A., Urbano, A., Haston, M. \& McMahon, E.(2010). School counselors' strategies for social justice change: A grounded theory of what works in the real world. Professional School Counseling, 13(3), 135-145.

Sink, C. (2008). Elementary school counselors and teachers: Collaborators for higher student achievement. Elementary School Journal, 108(5), 445458.

Shillingford, M. \& Lambie, G. W. (2010). Contribution of professional school counselors' values and leadership practices to their programmatic service delivery. Professional School Counseling, 13(4), 208-217.

Smith, J. S., Akos, P., Lim, S. \& Wiley, S. (2008). Student and stakeholder perceptions of the transition to high school. The High School Journal, 91 (3), 32-42.

Somody, C, Henderson, P., Cook, K.\& Zambrano, E.. (2008). A working system of school counselor supervision. Professional School Counseling, 12 (1), 22-33.

Toporek, R., Blando, J.,Chronister, J., Kwong-Liem, K., Hsin-Ya, L. \& Van Velsor, P..(2009). Counselor to the core: serving the whole client through creative blending of counselor roles. Counseling \& Human Development, 41(5), 1-16.

Walsh, M.E., Barrett, J.G. \& DePaul, J. (2007). Day-to-day activities of school counselors: Alignment with new directions in the field and the ASCA national model. Professional School Counseling, 10(4), 370-378.

Ward, S., Evans, C. \& Couts, Pat. (2010). School counseling and school educational leader preparation programs: Partnerships in training skills in open communication. National Social Science Journal, 34(1), 151-156.

Wilkerson, K. \& Eschbach, L.A. (2009). Transformed school Counseling: The Impact of a graduate course on trainees' perceived readiness to develop comprehensive, data-driven programs. Professional School Counseling, 13(1), 30-37. 